\title{
Review
}

\section{Kinetic Study of Copper Retention by Kaolin Using a System of Supports Designed in 3D}

\author{
A. Macías-García ${ }^{1}$, J. E. Calderón-Rios ${ }^{1}$, M. A. Díaz-Díez ${ }^{1}$, D. Torrejón-Martín, J. P. Carrasco-Amador ${ }^{\star}$ \\ 'Department of Mechani cal, Energetic and Materials Engineering, School of Industrial Engineering, University of \\ Extremadura, Badajoz 06006, Spain. \\ ${ }^{2}$ Department of Graphic Expression, School of Industrial Engineering, University of Extremadura, Badajoz 06006, Spain.
}

Correspondence to: J. P. Carrasco-Amador, Department of Graphic Expression, School of Industrial Engineering, University of Extremadura, Avda. de Elvas, s/n, Badajoz 06006, Spain. E-mail: jpcarrasco@unex.es

Cite this article: Macías-García A, Calderón-Rios JE, Díaz-Díez MA, Torrejón-Martín D, Carrasco-Amador JP. Kinetic Study of Copper Retention by Kaolin Using a System of Supports Designed in 3D. Adv Mat/ Sci Tech2020;2:1:17-28.

Published: Jun 2020

\begin{abstract}
Kaolin is a clay product of the decomposition of feldspatic rocks; it is a hydrated aluminum silicate whose main component is kaolinite; its formula is $2 \mathrm{H}_{2} \mathrm{O}-\mathrm{Al}_{2} \mathrm{O}_{3}-2 \mathrm{SiO}_{2}$ and it has a wide application in various industries. In this study copper ions removal of aqueous solutions using kaolin, was investigated. Kaolin sample are texturally and chemically characterized and its electrical conductivity was established, and finally diverse kinetic models were tested to the copper ion retention process. Kinetic adsorption and electroadsorption processes of $\mathrm{Cu}$ (II) ions on kaolin are practically identical. The $\mathrm{q}_{\mathrm{e}}$ values for both adsorption and electroadsorption are of the order of $10.1 \mathrm{mg} \cdot \mathrm{g}^{-1}$ for an equilibration time of $1200 \mathrm{~min}$. This suggests that adsorption procedure is the determining factor. In view of results, we can indicate that kinetic adsorption procedure of $\mathrm{Cu}$ (II) ions on kaolin is adjusted to a pseudo second order kinetics. High regression coefficients are reached, greater than those of first order pseudo model, with worths above 0.99. Its explanation comes from the valence forces involved in the adsorption mechanism, due to electrons exchange between $\mathrm{Cu}$ (II) ions and the adsorbent. Likewise, correlation between experimental $\mathrm{q}_{\mathrm{e}}$ values, and the calculated $\mathrm{q}_{\mathrm{e}}$, through the kinetic model are good. A more detailed observation through intraparticle diffusion model allows us to distinguish two well defined linear parts, a first one: that would correspond to the transport of ions from the dissolution to the external covering of the absorbent, with a fast ions distribution on the external kaolin covering. And a second part, which symbolize the intraparticular diffusion, as well as $\mathrm{Cu}$ (II) union with the kaolin internal active sites.
\end{abstract}

Keywords

Kaolin; copper; adsorption; kinetic

\section{INTRODUCTION}

Kaolin is a hydrated aluminum silicate, product of the decomposition of feldspatic rocks mainly. The term 
kaolin refers to clays in which the mineral kaolinite predominates; it can have different colors due to impurities; generally earthy matt shine; it is hygroscopic (absorbs water); its plasticity is low to moderate ${ }^{[1]}$.

Other important properties are its whiteness, its inertia against chemical agents, odourless, electrical insulator, moldable, resists high temperatures, is non-toxic and non-abrasive and has high refractivity and dispersion ease. It is compact, soft to the touch and hardly fusible. It has great absorbing power and low viscosity ${ }^{[2-4]}$.

Global kaolin consumption was estimated around 24.8 million metric tons by 2013 . There are about 277 large deposits in countries such as: United States, England, Brazil, Indonesia, China, Spain, etc., where kaolin is extracted and treated to purify it, and thus, take advantage of its properties ${ }^{[5]}$.

Kaolin has many industrial applications (paper, ceramics, refractories, paints, plastics, agrochemicals, pharmaceuticals, medicine, cosmetics, constructions, electrical material, adsorption, etc. $)^{[6-10]}$.

Copper is part of numerous industrial and technological processes of great importance. The demand for copper is growing day by day. Copper can be liberated in the environment by human activities and/or natural processes. Examples of natural sources are dust storms, vegetation decomposition, forest fires, etc. On the other hand, human activities can contribute to the liberation of copper in mining, metal production, phosphate fertilizer production $^{[11,12]}$, etc.

On the other hand, prolonged exposure to copper can irritate the nose, mouth and eyes and cause headache, dizziness, vomit and diarrhea. A large copper exposure can cause damage to the liver and kidneys and even death $^{[13,14]}$.

In other words, copper causes serious environmental and human health problems. For this reason, countries with large mining production, such as Chile, have established that for production processes, only alternative waters such as seawater or wastewater will be used. Also proposing to incorporate wastewater treatments to reduce local pollution ${ }^{[15-17]}$.

The aim of this work is to use kaolin, a highly adsorbent material, to remove copper from wastewater.

\section{EXPERIMENTAL}

\subsection{Adsorbent and Adsorbate}

The kaolin (Minas La Zarza S. A.) was used as the starting material, mean while as absorbate a copper salt $\left[\mathrm{Cu}\left(\mathrm{SO}_{4}\right)_{2} \cdot 5 \mathrm{H}_{2} \mathrm{O}\right]$ supplied by Panreac, with a concentration of $25 \mathrm{ppm}$ prepared with ultrapure water obtained with an Ultrapure Milli-QTM equipment.

\subsection{Characterization of the Kaolin}

\subsubsection{Chemical Characterization of the Adsorbent}

Chemical composition of the sample was determined by chemical analysis (supplied by the company). Surface functional groups, as well as sample structures, were tested by FT-IR spectroscopy. Spectra were examined in a Perkin Elmer 1720 spectrometer, with wavelengths in the range of 4000 to $400 \mathrm{~cm}^{-1}$, taking 50 scans with a 2 $\mathrm{cm}^{-1}$ resolution.

\subsubsection{Textural Characterization of the Adsorbent}

Kaolin textural characterization was accomplished by nitrogen adsorption and mercury porosimetry. Nitrogen adsorption at $196^{\circ} \mathrm{C}$, with an apparatus Autosorb-1 (Quantachrome ${ }^{\circledR}$ ), was utilized to study the specific surface and volume of narrow micropores and mesopores. A mercury porosimeter Autoscan-60 (Quantachrome ${ }^{\circledR}$ ) was used to determine the volume of wide mesopores and macropores.

\subsection{Electrical Conductivity}

The electrical conductivity, DC $(\sigma)$ at room temperature was determined using a method developed by us and 
described in previous works ${ }^{[18]}$. For this, the impedance spectroscopy technique was used, with frequencies between 20 and $10^{6} \mathrm{~Hz}$, at $1 \mathrm{~V}$ voltage and a kaolin mass of approximately $0.10 \mathrm{~g}$, previously dried in the oven at $110^{\circ} \mathrm{C}$ overnight.

\subsection{Analytical Method}

A Perkin Elmer Flame Atomic Absorption Spectrometer, Thermo Corporation Model, employing an airacetylene flame, was employed to measure $\mathrm{Cu}$ (II) concentration. Hollow cathode $\mathrm{Cu}(\lambda=324.8 \mathrm{~nm})$ lamps, from the same producer, were utilized as radiation sources.

\subsection{Kinetic Experiments}

A determinated fixed quantity of absorbent $(0.1 \mathrm{~g}$ of kaolin) and of adsorptive solution $(80 \mathrm{~mL})$, with a beginning concentration of $25 \mathrm{ppm}$, were combined at unchanging temperature for a previously set space time, to examine adsorption kinetics [Figure 1] ${ }^{[19]}$. In the holes of the adapter in the figure, made by 3D printing, the bottles filled with adsorbate and adsorbent are placed and placed in an electronic thermostatic bath at $25{ }^{\circ} \mathrm{C}$ with a stirring speed of 40 oscillations per minute.

For the electroadsorption process, the same kaolin mass and the same concentration of copper ions will be affected. In a cell with two electrodes made of kaolin and sometimes a voltage of $1 \mathrm{~V}$, the copper ion solution is added. The cell is placed on a magnetic stirrer with a stirring speed of 40 oscillations per minute and a temperature of $25^{\circ} \mathrm{C}$.

Kaolin electrodes are made by mixing kaolin with water until a moldable mixture is obtained and with a mold the cylindrical electrodes $1 \mathrm{~cm}$ in diameter and $5 \mathrm{~mm}$ thick are extracted and sintered in an oven.

To study the progress of adsorption/electroadsorption procedure in time, solute concentration was examined as detailed in an earlier part. The equilibrium time, $\mathrm{t}_{\mathrm{e}}$, can be interpreted as the minimal period of time needed to maintain the concentration value unalterable (i.e., to get the equilibrium concentration or $\mathrm{C}_{\mathrm{e}}$ ).

Establishing the adsorbed quantity $\mathrm{q}_{\mathrm{t}}\left(\mathrm{mg} \cdot \mathrm{g}^{-1}\right)$ at given time, $\mathrm{t}$, by the mass balance Eq. (1):

$$
q_{t}=\frac{\left(C_{0}-C_{t}\right) \cdot V}{W}
$$

Where $\mathrm{q}_{\mathrm{t}}$ represents solute mass $(\mathrm{mg})$ adsorbed onto $0.1 \mathrm{~g}$ of adsorbent at a time $t ; C_{0}$ is $\mathrm{Cu}$ (II) concentration $\left(\mathrm{mg} \cdot \mathrm{L}^{-1}\right)$, originally existing in the dissolution; $C_{t}$ assumes the role of the $\mathrm{Cu}$ (II) concentration $\left(\mathrm{mg} \cdot \mathrm{L}^{-1}\right)$ at time, $t ; V$ stands for solution volume (L) in each adsorption cell; and $W$ is kaolin mass $(g)$ combined with dissolution.

The adsorption process is influenced by the adsorbent chemical and physical properties, as well as the mass transfer procedure from adsorbate to adsorbent ${ }^{[20,21]}$.

Kinetics of the adsorption/electroadsorption process reveals the evolution of each step, as well as which one leads the procedure (chemical reaction, diffusion and/or mass transfer).

In this investigation, both adsorption reaction kinetic models, pseudo-first order and pseudo-second order, and one adsorption diffusion model (intraparticle diffusion) were used, to analyse $\mathrm{Cu}$ (II) ion adsorption kinetics onto kaolin adsorbent.

\subsubsection{Pseudo First Order Model}

Pseudo first order Lagergren equation is one of the most widely employed equations in adsorption kinetics ${ }^{[22,23]}$.

This equation assumes that metal ion is set a site of adsorption of adsorbent material, which can be expressed as: 


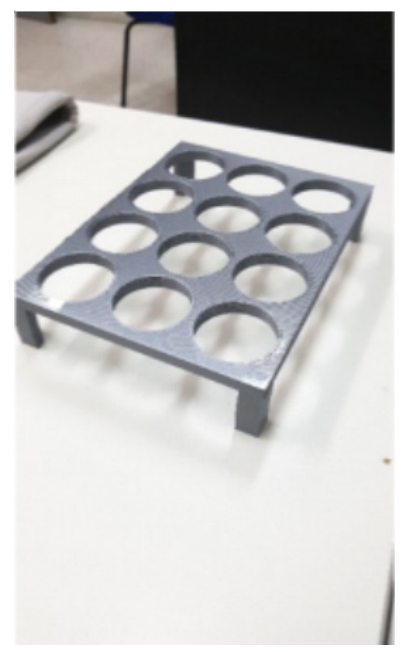

Figure 1. Adapter in 3D incorporated into a thermostatic bath for kinetic study ${ }^{[19]}$.

$\frac{d q_{t}}{d t}=k_{1}\left(q_{e}-q_{t}\right)$

Where $k_{l}$ represents the adsorption rate constant $(1 / \mathrm{s}) ; q_{t}$ indicates $\mathrm{mg}$ of solute hold per adsorbent mass unit at a determined time, $t(\mathrm{mg} / \mathrm{g}) ; q_{e}$ is $q$ value $(\mathrm{mg} / \mathrm{g})$, got once the equilibration time, $t_{e}$, is passed.

Eq. (2) may be integrated as:

$\log \left(q_{e}-q_{t}\right) \log q_{e}-\frac{k_{1}}{2303} t$

Therefore, if kinetic data fit to the pseudo-first order model, a graph of $\log \left(q_{e}-q_{t}\right)$ versus $t$, would result in a straight line. Thus, the slope and the intersection of this line could be used to settle values of $k_{l}$ and $q_{e}$, respectively.

\subsubsection{Pseudo Second Order Model}

Blanchard et $a l .{ }^{[24]}$ presented the pseudo-second order kinetic model, which was later modified by Ho ${ }^{[25]}$. This pattern presumes that adsorbate is adsorbed in two different active areas of the activated carbon.

The equation corresponding to this pattern is:

$\frac{d q_{t}}{d t}=k_{2}\left(q_{e}-q_{t}\right)^{2}$

Where $k_{2}$ is the adsorption rate constant of pseudo-second order model ( $\left.\mathrm{g} / \mathrm{mg} \mathrm{min}\right)$. The integrated form of Eq. (4) is:

$$
\frac{t}{q_{t}}=\frac{1}{k_{2} q_{s}^{2}}+\frac{1}{q_{s}} t
$$

Thus, from slope and intersection, of the $t / q$ versus $t$ graphs, it is possible to calculate the values of $q_{e}$ and $k_{2}$ for the kinetic model pseudo-second order.

\subsubsection{Intraparticle Diffusion model}

Weber and Morris intraparticle diffusion model assumes that adsorption procedure could be managed by one of the next stages such as: film diffusion, pore diffusion, surface diffusion, adsorption onto the adsorbent pore surface, or a combination of several stages ${ }^{[26,27]}$.

Intraparticle diffusion is characterized by the relationship between specific adsorption and the square root of the time. Coinciding the slope with the intraparticle diffusion rate ${ }^{[28,29]}$. 
Table 1. Chemical composition of the raw material

\begin{tabular}{ll}
\hline Oxides & (\%) \\
\hline $\mathrm{SiO}_{2}$ & 53.40 \\
$\mathrm{Al}_{2} \mathrm{O}_{3}$ & 32.00 \\
$\mathrm{Fe}_{2} \mathrm{O}_{3}$ & 2.90 \\
$\mathrm{CaO}$ & 0.10 \\
$\mathrm{TiO}_{2}$ & 2.00 \\
$\mathrm{MgO}$ & 1,03 \\
$\mathrm{~K}_{2} \mathrm{O}$ & 2.76 \\
$\mathrm{Na}_{2} \mathrm{O}$ & 0.21 \\
$\mathrm{H}_{2} \mathrm{O}$ & 5.60 \\
\hline
\end{tabular}

Thus, the equation that describes the intraparticle diffusion is:

$q_{t}=k_{i d} t^{1 / 2}+C$

With $k_{i d}$ representing the intraparticle diffusion rate constant $\left(\mathrm{mg} / \mathrm{g} \min ^{1 / 2}\right)$ and $\mathrm{C}(\mathrm{mg} / \mathrm{g})$ a parameter connected to limit layer thickness. Usually, high values of C, produces noticeable limit layer effects. That is, if $q_{t}$ versus $t^{1 / 2}$ graph gives a straight line going through the origin, then it could be expected that adsorption procedure will be mostly regulated by intraparticle diffusion. Conversely, if $q_{t}$ versus $t^{1 / 2}$ graph shows more than one single linear plot, then it coud be assumed that adsorption procedure is made up of two or more single stages.

\section{RESULTS AND DISCUSSION}

\subsection{Raw Materials}

\subsubsection{Chemical Characterization}

Kaolin has been characterized by the determination of its chemical composition. These results are shown in Table 1.

The results obtained are quite similar to those described by other authors ${ }^{[30,31]}$. The chemical composition indicates that it is a silico-aluminous compound with small quantities of other elements.

According to the literature consulted ${ }^{[31]}$, kaolinite was associated with pyrophyllite-sericite. However, chemical analysis of the raw material revealed a significant absence of pyrophyllite. This fact is explained by different authors ${ }^{[31,32]}$ and can be explained by two possible hypotheses. A first is to assume that clayey sedimentary rocks possess quartz, mica and kaolinite minerals. The proportion will vary according to sedimentation conditions and the possibility of kaolinite contribution from a rich zone to the rock.

The second hypothesis would be that part of the kaolinite has been formed by kaolinization of feldspars (which possess them in small quantities) and micas. The kaolin would then be a mineral of neoformation that could be formed by meteorization and also perhaps by hydrothermalism since both processes are described in this zone by different authors ${ }^{[30,33]}$.

On the other hand, the analysis of the results in Table 1 shows the absence of heavy metals, which is good for different applications, such as pharmaceutical, adsorption, etc., among others.

For more information on the raw material, the FT-IR spectrophotometric study was carried out. Table 2 shows the information provided by the FT-IR spectrum.

The associated bands correspond to the vibrations of the bonds in their structure, $\mathrm{Si}-\mathrm{O}$ of the silicon tetrahedra, $\mathrm{Al}-\mathrm{O}$ and $\mathrm{Al}-\mathrm{OH}$ of the aluminium octahedra and $\mathrm{Si}-\mathrm{O}-\mathrm{Al}$ of the $\mathrm{SiO}^{4-}$ and $\mathrm{AlO}^{4-}$ bonds. A wide band of about $3622 \mathrm{~cm}^{-1}$, related to the $\mathrm{OH}$ - groups, can be assigned to low crystallinity kaolins ${ }^{[34]}$. On the other hand, a band was observed at $1635 \mathrm{~cm}^{-1}$ corresponding to water molecules occluded inside the clay sheets. Also, bands are observed in 1033 and $923 \mathrm{~cm}^{-1}$ according to the $\mathrm{Si}-\mathrm{O}$ and $\mathrm{Al}-\mathrm{O}$ vibrations of Al-O-H group, and others attributable to Si-O-Al ${ }^{[35]}$ located at 788,700 and $533 \mathrm{~cm}^{-1}$. 
Table 2. Information of the FT-IR spectrum

\begin{tabular}{ll}
\hline Functional group & Wave number $\left(\mathbf{c m}^{-1}\right)$ \\
\hline$-\mathrm{OH}$ & 3622 \\
$\mathrm{H}_{2} \mathrm{O}$ & 1635 \\
$\mathrm{Si}-\mathrm{O}$ & 1033 \\
$\mathrm{Al}-\mathrm{O}$ & 923 \\
$\mathrm{Si}-\mathrm{O}-\mathrm{Al}$ & $788,700,533$ \\
\hline
\end{tabular}

\subsubsection{Textural Characterization}

Table 3 shows the results corresponding to the porous texture of kaolin.

Table 3 shows that the $\mathrm{S}_{\mathrm{BET}}$ specific surface area of kaolin is low, $32 \mathrm{~m}^{2} \cdot \mathrm{g}^{-1}$, compared to other porous materials and probably due to kaolinite. This low value of the $S_{B E T}$ surface may be related with the low crystallinity, manifested in the study of FT-IR spectra. However, the presence of this surface area together with its porosity distribution, fundamentally meso-macroporous, can be favourable for the utilisation of kaolinite, which forms part of kaolin, in the adsorption processes, since it is superior to that presented by kaolinites of high crystallinity $^{[34]}$.

\subsubsection{Electrical Conductivity}

According to the literature, we can indicate that electrical conductivity in porous materials depends fundamentally on porosity distribution, chemical surface ${ }^{[36]}$, physical and chemical properties ${ }^{[37]}$, textural $\operatorname{properties}^{[38]}$.

From Figure 2, it can be seen that kaolin is a material with generally very low electrical conductivity values. These values are increased by the pressure, as the number of contact between the particles increases, thus favouring the passage of the electrical current.

The results show that this material, and particularly the kaolinite present, is largely in amorphous form, which influences the low electrical conductivity of this material.

The low conductivity presupposes that kaolin is not a good material for the study of electrical applications that are not properly electrical insulators. However, it would be of great interest to carry out chemical modification or doping with other compounds in order to modify their electrical properties and to be able to carry out further studies of this material.

\subsection{Kinetic Study}

The kinetic study of the $\mathrm{Cu}$ (II) ions adsorption/electro-absorption in aqueous solution has been carried out in two stages. A first one is based on the discussion of the kinetics of the $\mathrm{CuSO}_{4}$ adsorption and electro-absorption process on kaolin and a second one applying different kinetic models. Electro-absorption was determined using a voltage of $0.3 \mathrm{~V}$.

The figure shows that the kinetic processes of adsorption and electro-absorption of $\mathrm{Cu}$ (II) ions on kaolin are practically identical. This seems to indicate that the adsorption process is the determining factor. The electroadsorption process is conditioned by the adsorption process. Therefore, we can conclude that the electroabsorption process does not exert any influence or little influence on the $\mathrm{Cu}$ (II) ion retention process by kaolin. This circumstance could be associated, by one side, to the kaolin structure that would favour a low electrical conductivity, and, on the other side, with the composition of kaolin, which is formed by different materials, where kaolinite has the highest capacity adsorption ${ }^{[39]}$.

In Figure 3, we can see that $\mathrm{Cu}$ (II) ions retention by kaolin occurs at very small times, as shown in the first part of figure. 


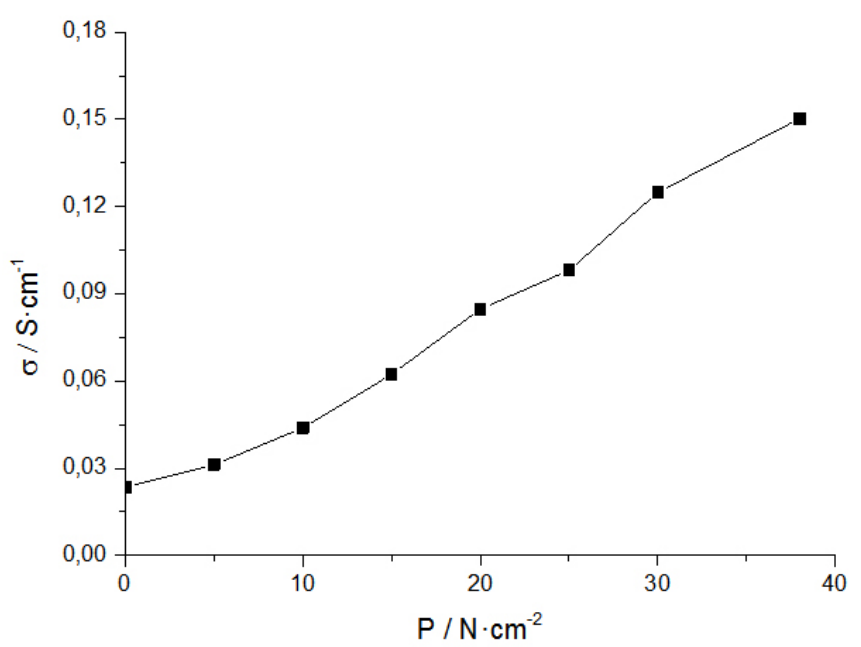

Figure 2. Variation of the electrical conductivity of kaolin with pressure.

Table 3. Textural parameters of kaolin

\begin{tabular}{llllll}
\hline Sample & $\mathbf{S}_{\text {BET }}\left(\mathbf{m}^{2} \cdot \mathbf{g}^{-1}\right)$ & $\mathbf{V}_{\mathbf{m i}}\left(\mathbf{c m}^{3} \cdot \mathbf{g}^{-1}\right)$ & $\mathbf{V}_{\mathbf{m e}}\left(\mathbf{c m}^{3} \cdot \mathbf{g}^{-1}\right)$ & $\mathbf{V}_{\text {me-p }}\left(\mathbf{c m}^{\mathbf{3}} \cdot \mathbf{g}^{-1}\right)$ & $\mathbf{V}_{\text {ma-p }}\left(\mathbf{c m}^{3} \cdot \mathbf{g}^{-1}\right)$ \\
\hline Kaolín & 32 & 0.008 & 0.010 & 0.080 & 0.090 \\
\hline
\end{tabular}

Table 4 shows values corresponding to equilibrium times and $\mathrm{Cu}$ (II) ions concentration retained by the kaolin.

The table shows that the values for the adsorption and electro-absorption processes are the equal. The concentration of copper ions retained by the kaolin is higher than the concentration retained by some activated carbons. This fact explains why Kaolin is used in numerous industrial applications and especially in pharmaceuticals.

The $\mathrm{q}_{\mathrm{e}}$ and $\mathrm{t}_{\mathrm{e}}$ values in the adsorption and electro-absorption processes together with the low electrical conductivity values of kaolin explain that this material is not apt for electro-absorption process where ion mobility is very important.

\subsubsection{Kinetic Models of Processes}

According to the results obtained, a study of the kinetic models for adsorption process will be performed. The generation and/or adjustments of analytical models for the study of dynamic systems generate abstractions of the these systems ${ }^{[40]}$, identifying the variables that explain the response as optimizing the dependent variable depending on the domain or range of operation of the independent variables ${ }^{[41]}$. Kinetic adsorption models provide very important information in copper ions retention procedure in waste water. Different kinetic models have been tested in this study. From the application of these models, the velocity constant of each kinetic equation has been determined and statistical parameters such as the regression coefficient have been calculated.

1. First-order pseudo model

Figure 4 shows first order pseudo equation (Ec. 3.21) for $\mathrm{Cu}$ (II) ion adsorption process by kaolin.

Table 5 presents the values of speed constant $\mathrm{k} 1$ and correlation coefficient $\mathrm{R}$.

Table 5 and Figure 4 results demonstrate that kinetic data of $\mathrm{Cu}$ (II) ion adsorption in kaolin does not fit the first-order pseudo model, so the process is not a first order reaction. Thus, in view of the data presented in Table 5 it is observed that on the one hand, the values of $\mathrm{R}^{2}$ are in the order of 0.8 and on the other hand, the value of experimental $\mathrm{q}_{\mathrm{e}}$ [Table 3] is $10.1 \mathrm{mg} \cdot \mathrm{g}^{-1}$ and calculated value from first order pseudo model is 3.34 $\mathrm{mg} \cdot \mathrm{g}^{-1}$. Similarly, it has been found in other research ${ }^{[42]}$ that this model is not the most appropriate for adjusting 


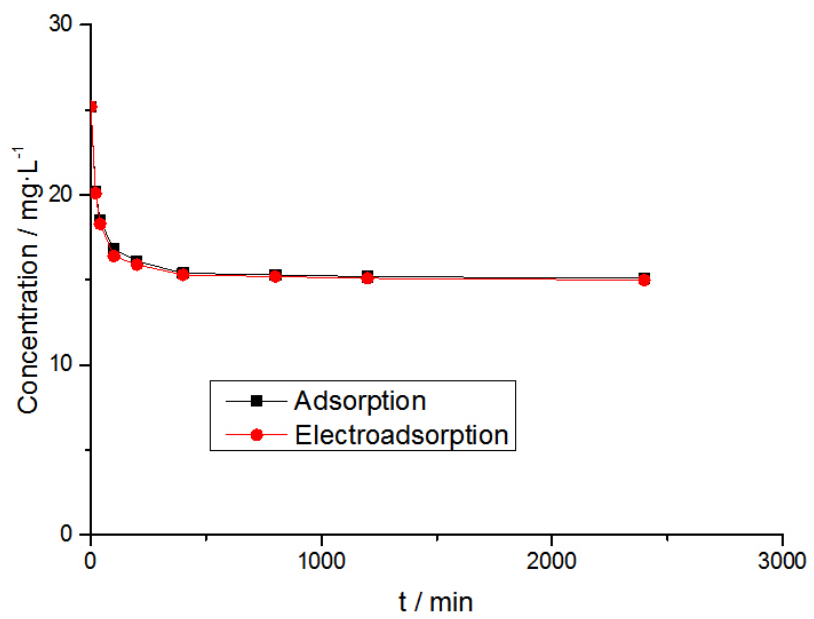

Figure 3. Variation in $\mathrm{Cu}$ (II) ion concentration with time.

Table 4. Values corresponding to the equilibrium times and concentration of $\mathrm{Cu}$ (II) ions retained by the kaolin

\begin{tabular}{|c|c|c|c|c|}
\hline Samples & $t_{e}$ /adsorption (min) & $\mathrm{q}_{\mathrm{e}} /$ adsorption (mg: $\mathrm{g}^{1}$ ) & $t_{e} /$ electroadsorption (min) & $\mathrm{q}_{\mathrm{e}} / \mathrm{electroadsorption}\left(\mathrm{mg} \cdot \mathrm{g}^{-1}\right)$ \\
\hline Kaolin & 1200 & 10.1 & 1200 & 10.2 \\
\hline
\end{tabular}

adsorption kinetics data to carbonaceous materials.

2. Second order pseudo model

Experimental data of $\mathrm{Cu}$ (II) ion adsorption by kaolin were adapted to a pseudo-second order kinetic model and graphically represented in Figure 5. Values of adsorption velocity, regression coefficient $\mathrm{R}^{2}$ and speed constant $\mathrm{k}_{2}$ are given in Table 5 .

Likewise, the regression coefficient corresponding to the adjustment of experimental data to the pseudo-second order model confirms a good adjustment $\left(\mathrm{R}^{2}\right.$ in the order of 0.999$)$. As well as the values of experimental $\mathrm{q}_{\mathrm{e}}$ Table $4\left(10.1 \mathrm{mg} \cdot \mathrm{g}^{-1}\right)$ present a good correlation with the value calculated through the pseudo-second order model Table $5\left(8.3 \mathrm{mg} \cdot \mathrm{g}^{-1}\right)$. Therefore, in view of the results, we can indicate that kinetic adsorption procedure of $\mathrm{Cu}$ (II) ions on kaolin is adjusted to a pseudo second order kinetics.

The adsorption mechanism, involving valence forces through the sharing or exchange of electrons between $\mathrm{Cu}$ (II) ions and adsorbent, produces regression coefficients are higher than first order pseudo model ones, with levels above 0.990. Likewise, correspondence between experimental $\mathrm{q}_{\mathrm{e}}$ values, Table 4, and determined $\mathrm{q}_{\mathrm{e}}$, Table 5, through kinetic model are correct.

3. Intraparticle diffusion

This model is usually used to carry out studies of the ion diffusion mechanism in samples ${ }^{[43,44]}$.

According to others authors ${ }^{[45]}$, diffusion mechanisms of ions on a porous adsorbent take place by transporting the ions in two stages, one from dissolution to the surface of the adsorbent and the other intraparticle, from the surface to the union with the surface groups.

The aim of this type of study is to determine which of the two previous stages is predominant. For some authors $^{[45]}$, if intraparticle diffusion is the restricting step of procedure speed, the graph representation of quantity of copper ions retained in front to the square root of the contact time should perform a straight line, which will cross the coordinates origin ${ }^{[45]}$. In accordance with the above, in $\mathrm{Cu}$ (II) ion adsorption procedure on kaolin, Figure 6, a multilinearity graph is shown. 


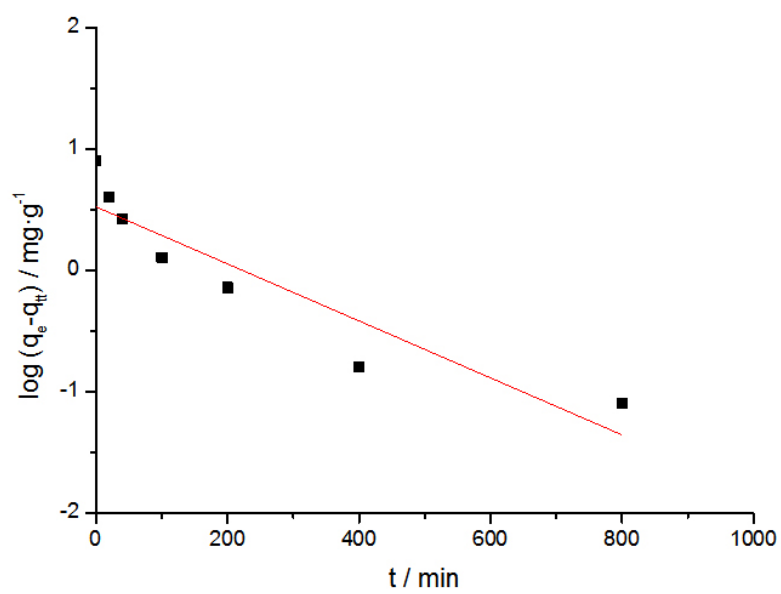

Figure 4. Graphic representation of the pseudo first order model for the Cu (II) ion adsorption process by kaolin.

Table 5. Kinetic parameters

\begin{tabular}{|c|c|c|c|c|c|c|c|}
\hline \multirow[t]{2}{*}{ Sample } & \multicolumn{3}{|c|}{ First-order pseudo } & & \multicolumn{3}{|c|}{ Second-order pseudo } \\
\hline & $q_{e}$ & $\mathbf{k}_{1}$ & $\mathbf{R}^{2}$ & & $q_{e}$ & $\mathbf{k}_{2}$ & $\mathbf{R}^{2}$ \\
\hline \multirow[t]{4}{*}{ Kaolin (Ads.) } & 3.34 & $5.53 \cdot 10^{-3}$ & 0.8353 & & 8.10 & $7.65 \cdot 10^{-3}$ & 0.9997 \\
\hline & \multicolumn{4}{|c|}{ Diffusion } & & & \\
\hline & $\mathrm{C}$ & $\mathbf{k}_{\mathrm{id}}$ & & $\mathbf{R}^{2}$ & & & \\
\hline & 0.01 & 1.2 & & 0.9958 & & & \\
\hline
\end{tabular}

A more detailed observation of the figure allows us to distinguish two well-defined linear parts, a first one between 0 and $10 \mathrm{~min} 1 / 2$, that would correspond to the transport of ions from solution to the external adsorbent surface with a fast ions distribution on the outer kaolin surface. That is, the kinetic process of ion retention occurs very quickly when adsorbent and adsorbate contact take place [Figure 6]. This behaviour has already been observed in other adsorbents. Second linear section fits to the adsorption period, between 10 and 38 min $1 / 2$, describing the intraparticle diffusion and $\mathrm{Cu}$ (II) union with the internal active kaolin sites.

Table 5 shows kinetic parameters for intraparticle diffusion. A regression coefficient (R2) of the order of 0.996 is observed, which permits us to say that this is a good adjustment.

\section{CONCLUSION}

The present work has been carried out with the intention of being able to use a material such as kaolin in the decontamination of wastewater contaminated with copper ions.

From the previous characterization of kaolin and its application in adsorption and electroadsorption processes, it is concluded that:

Chemical characterization, porous texture and electrical conductivity have been carried out. Kaolin has been selected as an adsorbent material based on its chemical, textural and electrical properties for application in the adsorption/electroadsorption process.

Kaolin has an adequate proportion of mesopores, which makes its surface electrochemically accessible to ions, so that they can be transported quickly.

Kaolin is a material contaminated with other ceramic materials, which negatively influences its adsorbent behaviour. 


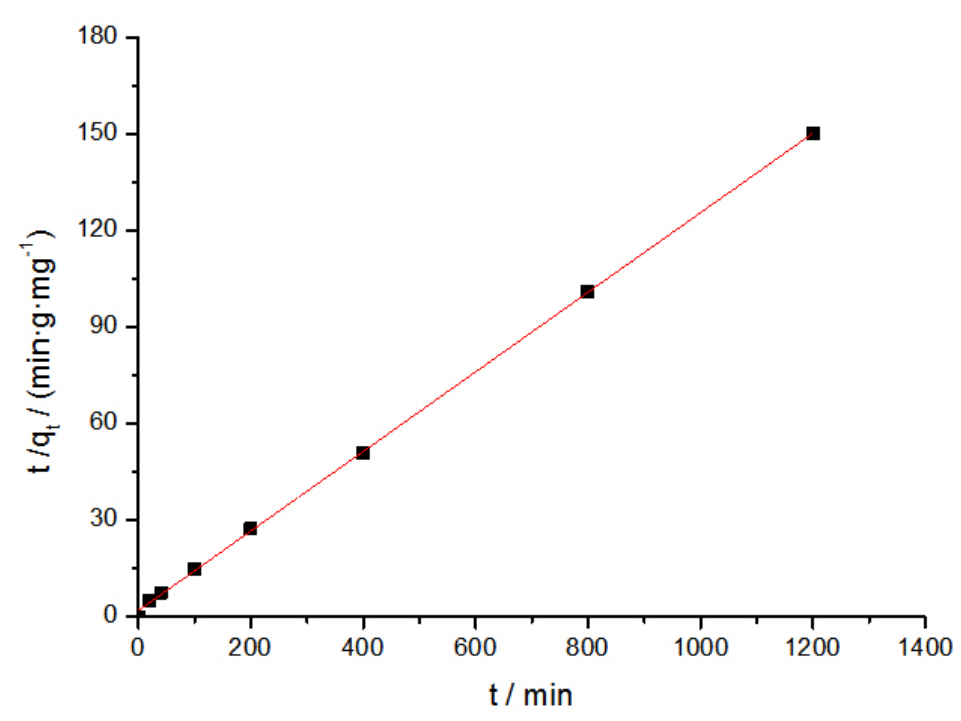

Figure 5. Graphic representation of the second order pseudo model for the $\mathrm{Cu}$ (II) ion adsorption process by kaolin.

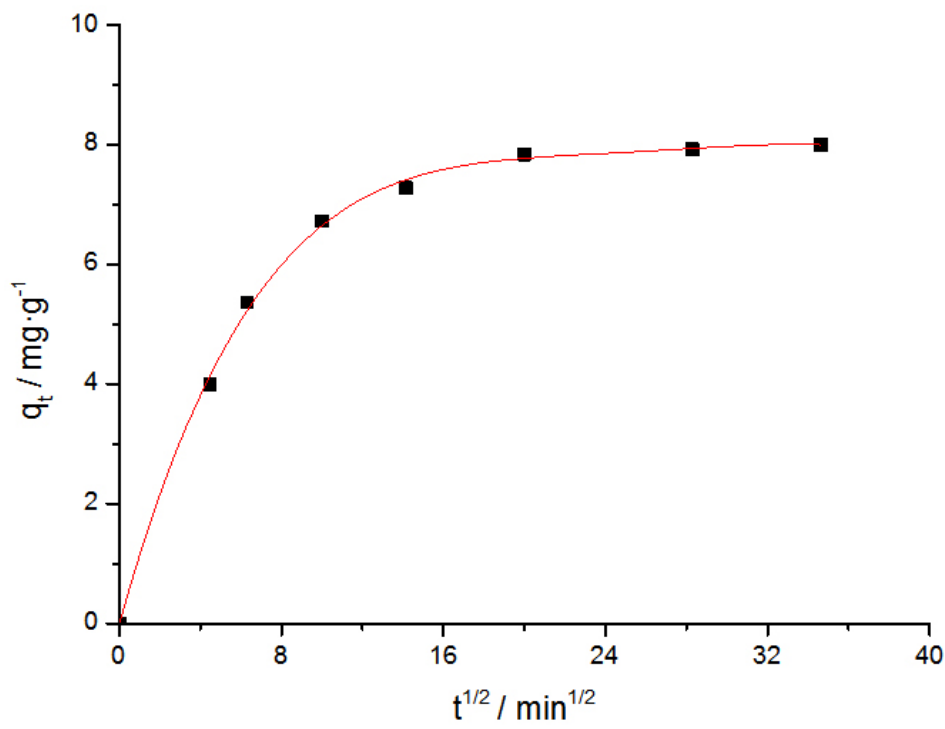

Figure 6. Graphic representation of the intraparticle diffusion model for the $\mathrm{Cu}$ (II) ion adsorption process by kaolin.

The adsorbent capacity of kaolin is similar to other porous materials and can be a good substitute for them. In view of the results, everything seems to indicate that kaolinite is responsible of this good behaviour in adsorption process.

The electrical properties of kaolin and in particular the electrical conductivity is very low, making it inappropriate for some applications such as electroadsorption.

\section{REFERENCES}

[1] Bartolomé JF. El Caolín: composición, estructura, génesis y aplicaciones. Boletín de la Sociedad Española de Cerámica y Vidrio 1997,36(1):17-19.

[2] Murray HH. Applied clay mineralogy: occurrences, processing and application of kaolins, bentonites, palygorskite-sepiolite, and common clays. Elsevier 2006.

[3] Murray H. Chapter 5, Kaolin Applications Developments in Clay Science. 2006,2:85-109.

[4] Adkins T, Davis J, Manning C, Phillips M, Sare EJ. Kaolin particle size distribution effects on whitewares-related performance properties. Chapter in Science of Whitewares. Carty WM, Sinton CW, eds. American Ceramic Society, Westerville, OH, 2000:121- 
130.

[5] Prasad MS, Reid KJ, Murray HH. Kaolin: processing, properties and applications. Applied Clay Sci 1991,6(2):87-119.

[6] Welch L, Dahlquist R. Kaolin clay in the paper industry. Intern Rep J M Huber Corporation 1984:1-36.

[7] Ekosse G. The Makoro kaolin deposit, southeastern Botswana: its genesis and possible industrial applications. Applied Clay Sci 2000,16:301-320.

[8] Abd El-Rahiem FH, Hassan MS, Selim KA, Abdel-Khalek NA. Evaluation and beneficiation of syrian kaolin for different industrial applications. J Ore Dressing 2008,10:34-41.

[9] Dang TH, Chen BH, Lee DJ. Optimization of biodiesel production from transesterification of triolein using zeolite LTA catalysts synthesized from kaolin clay. J Taiwan Inst Chem Engineers 2017,79:14-22.

[10] Ömer Y, Yalcin A, Fuat G. Removal of copper, níkel, cobalt and manganese from aqueous solution by kaolinite. Water Res 2003,37(4):948-952.

[11] Agency for Toxic Substances and Disease Registry Division of Toxicolog. Atlanta, Georgia.

[12] Yu S, Van Der Meer R, Beynen AC. Excessive hepatic copper accumulation in jaundiced rats fed a high-copper diet. Biol Trace Elem Res 2002,88(3):255-269.

[13] Zietz BP, deVergara JD, Dunkelberg H. Copper concentrations in tap water and possible effects on infant's health-results of a study in Lower Saxony, Germany. Environ Res 2003,92(2):129-138.

[14] Zietz BP, Dieter HH, Lakomek M, Schneider H, Keßler-Gaedtke B, Dunkelberg H. Epidemiological investigation on chronic copper toxicity to children exposed via the public drinking water supply. Sci Total Environ 2003,301(1-3):127-144.

[15] Toro N, Briceño W, Pérez K, Cánovas M, Trigueros E, Sepúlveda R, Hernández P. Leaching of pure chalcocite in a chloride media using sea water and waste water. Metals Basel 2019,9:780.

[16] Toro N, Pérez K, Saldaña M, Jeldres RI, Jeldres M, Cánovas M. Dissolution of pure chalcopyrite with manganese nodules and waste water. J Materials Res Technol 2019,9(1):798-805.

[17] Pérez K, Jeldres R, Nieto S, Salinas-Rodríguez E, Robles P, Quezada V, Hernández-Ávila J, Toro N. Leaching of pure chalcocite in a chloride media using waste water at high temperature. Metals 2020,10(384):1-9.

[18] Sánchez-González J, Macías-García A, Alexandre-Franco MF, Gómez-Serrano V. Electrical conductivity of carbon blacks under compression. Carbon 2005,43:741-747.

[19] Macías-García A, Carrasco-Amador JP, Encinas-Sánchez V, Díaz-Díez MA, Torrejón-Martín D. Preparation of activated carbon from kenaf by activation with $\mathrm{H} 3 \mathrm{PO}$. Kinetic study of the adsorption/electroadsorption using a system of supports designed in 3D, for environmental applications. J Environment Chem Engineering 2019,7(4):103196.

[20] Kumar PS, Ramakrishnan K, Kirupha DS, Sivanesan S. Thermodynamic and kinetic studies of cadmium adsorption from aqueous solution onto rice husk. Braz J Chem Eng 2010,27(2):437-455.

[21] Kumar P, Singh H, Kapur M, Mondal MK. Comparative study of Malathion removal from aqueous solution by agricultural and commercial adsorbents. J Water Process Eng 2014,3:67-73.

[22] Lagergren S. About the theory of so-called adsorption of soluble substances. Sven Vetenskapsakad Handingarl 1898,24(4):1-39.

[23] Ho YS. Citation review of Lagergren kinetic rate equation on adsorption reactions. Scientometrics 2004,59(1):171-177.

[24] Blanchard G, Maunaye M, Martin G. Removal of heavy metals from waters by means of natural zeolites. Water Res 1984,18:1501.

[25] Ho YS, McKay GA. Comparison of chemisorption kinetic models applied to pollutant removal on various sorbents. Trans IChemE 1998,76B:332.

[26] Fierro V, Torné-Fernández V, Montané D, Celzard A. Adsorption of phenol onto activated carbons having different textural and surface properties. Microporous Mesoporous Mater 2008,111(1-3):276-284.

[27] Huang Y, Li S, Chen J, Zhang X, Chen Y. Adsorption of Pb(II) on mesoporous activated carbons fabricated from water hyacinth using H3PO4 activation: adsorption capacity, kinetic and isotherm studies. Appl Surf Sci 2014,293:160-168.

[28] Mittal A, Malviya A, Kaur D, Mittal J, Kurup L. Studies on the adsorption kinetics and isotherms for the removal and recovery of Methyl Orange from wastewaters using waste materials. J Hazard Mater 2007,148(1-2):229-240.

[29] Macias-García A, Gómez Corzo M, Alfaro Domínguez M, Alexandre Franco M, Martínez Naharro J. Study of the adsorption and electroadsorption process of $\mathrm{Cu}$ (II) ions within thermally and chemically modified activated carbon. J Hazardous Materials 2017,328:46-55.

[30] Huerto EG, Vivaldi JLM. Caolines españoles: Geología, minerología y génesis. Parte IV Depósitos Paleozoicos, Neógenos y Cuaternarios. Boletín Español de Cerámica y Vidrio 1974:523-546.

[31] Herranz Araújo P. Nota preliminar sobre el estudio geológico de las Sierras Paleozoicas entre Oliva de Merida y Hornachos (Badajoz). Semin de Estrat 1970,6:116.

[32] Hernández Pacheco F, Cabanas R. Memoria y hoja núm. 858 (El Viso ) del Mapa Geológico de España a 1:50.000 ./.G.M.E. Madrid 1968.

[33] Sánchez Cela V. Consideraciones petrogenéticas de las rocas dioríticas de la zona de Mérida. Est Geol 1971,27:305-310.

[34] Murray HH, Lyons SC. Further correlation of kaolinite crystallinity with chemical and physical properties. Clays Clay Minerals 1960,8:11-17.

[35] Urama L. Determinación de la capacidad de adsorción de urea mediante el uso de zeolitas phillipsita y stilbita bajo condiciones de membranas para diálisis. Tesis de pregrado. Universidad de Carabobo 2012.

[36] Ramosa ME, Bonellia PR, Cukierman AL. Physico-chemical and electrical properties of activated carbon cloths. Effect of inherent nature of the fabric precursor. Colloids and Surfaces A: Physicochem. Engineering Aspects 2008,324:86-92. 
[37] Pantea D, Darmstadt H, Kaliaguine S, Roy C. Electrical conductivity of conductive carbon blacks: influence of surface chemistry and topology. Applied Surface Sci 2003,217:181-193.

[38] Johnsen DL, Zhang Z, Emamipour H, Yan Z, Rood MJ. Effect of isobutane adsorption on the electrical resistivity of activated carbon fiber cloth with select physical and chemical properties. Carbon 2014,76:435-445.

[39] Ghosh D, Bhattacharyya KG. Adsorption of methylene blue on kaolinite. Applied Clay Sci 2002,20(6):295-300

[40] Saldaña M, Toro N, Castillo J, Hernández P, Navarra A. Optimization of the heap leaching process through changes in modes of operation and discrete event simulation. Minerals 2019,9(7):1-13.

[41] Saldaña M, Toro N, Castillo J, Hernández P, Trigueros E, Navarra A. Development of an analytical model for the extraction of manganese from marine nodules. Metals 2019,9(8):1-11.

[42] Coughlin RW, Kreysa G. Int Chem Eng 1984,24:595.

[43] Huang Y, Li S, Chen J, Zhang X, Chen Y. Adsorption of Pb(II) on mesoporous activated carbons fabricated from water hyacinth using H3PO4 activation: adsorption capacity, kinetic and isotherm studies. Appl Surf Sci 2014,293:160-168.

[44] Mittal A, Malviya A, Kaur D, Mittal J, Kurup L. Studies on the adsorption kinetics and isotherms for the removal and recovery of Methyl Orange from wastewaters using waste materials. J Hazard Mater 2007,148(1-2):229-240.

[45] Qiu H, Lu LV, Pan B, Zhang Q, Zhang W, Zhang Q. Critical review in adsorption kinetic models. J Zhejiang Univ Sci A 2009,10(5):716-724. 